\title{
Pengaruh Pemberian Ekstrak Daun Duwet (Syzigium cumini) Terhadap Gambaran Histologi Ginjal Tikus (Rattus novergicus) yang Diintoksikasi dengan Timbal Asetat
}

Fathur Rahman ${ }^{1}$, Biomechy Oktomalioputri², Miftah Irramah ${ }^{3}$

\begin{abstract}
Abstrak
Timbal adalah logam berat yang bersifat racun bagi lingkungan dan tubuh manusia. Logam berat ini dieliminasi oleh ginjal sebagai urin, sehingga jika terjadi paparan timbal yang lama maka dapat menyebabkan kerusakan pada ginjal. Daun duwet mengandung antioksidan seperti flavonoid, myricetin, quercetin, isoquercetin yang dapat menghambat dan memperlambat radikal bebas. tujuan: Mengetahui pengaruh pemberian ekstrak daun duwet terhadap gambaran histologi ginjal tikus yang diintoksikasi timbal asetat. Metode: Penelitian ini merupakan studi eksperimental dengan rancangan randomized post test only control group menggunakan 15 ekor tikus yang telah dibagi menjadi 3 kelompok yaitu kelompok kontrol negatif $(\mathrm{K}-)$ yang hanya diberikan pakan standar, kelompok kontrol positif $(\mathrm{K}+)$ yang diberikan pakan standar serta diberi timbal asetat $40 \mathrm{mg} / \mathrm{kgBB}$ secara oral, terakhir kelompok perlakuan (P1) yang diberikan pakan standar, dipaparkan timbal asetat $40 \mathrm{mg} / \mathrm{kgBB}$, dan ekstrak daun duwet dosis $150 \mathrm{mg} / \mathrm{kgBB}$. Penelitian dilaksanakan selama 28 hari, kemudian pada hari ke-29 tikus dimatikan kemudian diambil ginjalnya untuk dibuat menjadi preparat dan dibaca menggunakan skor Barthel Manja. Hasil: Terdapat perbedaan bermakna antara kelompok kontrol positif $(\mathrm{K}+)$ dengan kelompok yang diberikan perlakuan (P1), secara statistik didapatkan nilai $p<0,05$. Simpulan: Terdapatnya pengaruh pemberian ekstrak daun duwet terhadap gambaran histologi ginjal tikus yang diintoksikasi timbal asetat.
\end{abstract}

Kata Kunci: timbal asetat, ekstrak daun duwet, histologi ginjal

\section{Abstract}

Lead is a toxic heavy metal to environment and human body. Lead in body will be eliminated by kidneys in urine, if there is a long lead exposure it can cause damage to kidneys. Duwet leaves contain antioxidants such as flavonoid, myricetin, quercetin, isoquercetin which inhibit and slow down free radicals. Objectives: To determined effect of duwet leaf extract on histology of rat kidney which were intoxicated with lead acetate. Methods: This study was an experimental with randomized post test only control group design using 15 rats which were divided into 3 groups: negative control group ( $K-)$ only given standard feed, positive control group $(K+)$ given standard feed and lead acetate $40 \mathrm{mg} / \mathrm{kgBB}$ orally, and treatment group (P1) given standard feed, exposed to $40 \mathrm{mg} / \mathrm{kgBB}$ lead acetate, and duwet leaf extract $150 \mathrm{mg} / \mathrm{kgBB}$. The study was conducted for 28 days and on 29th day rats were turned off and their kidneys taken to be made into preparations and read using Barthel Manja score. Results: There was a significant difference between positive control group $(K+)$ and treated group $(P 1)$ in statistically obtained value of $p<0.05$. Conclusion: The presence of influence from duwet leaf extract administration on renal histology of rats that are intoxicated with lead acetate.

Keywords: lead acetate, duwet leaf extract, renal histology

Affiliasi penulis : 1. Prodi Pendidikan Dokter, Fakultas Kedokteran, Universitas Andalas, Padang, Indonesia. 2. Bagian Histologi, Fakultas Kedokteran, Universitas Andalas, Padang, Indonesia. 3.Bagian Fisika,

Fakultas Kedokteran, Universitas Andalas, Padang, Indonesia.
Korespondensi :Biomechy Oktomalioputri,

Email: biomechyolivia@yahoo.com Telp: 085364153757 


\section{PENDAHULUAN}

Logam berat adalah suatu elemen logam alami yang terdapat di lingkungan. Logam berat bisa ditemukan dalam bentuk unsur tunggal atau berpasangan dengan unsur lain, mereka mudah menguap dan mudah terangkut oleh partikel halus secara luas dan dalam skala yang besar. Beberapa logam yang termasuk logam berat adalah timbal, raksa, kadmium. ${ }^{1}$ Bagi lingkungan, timbal termasuk racun berat yang sangat berbahaya dan secara umum diketahui tersebar di seluruh dunia seperti pada tempat-tempat yang menggunakan bahan bakar yang mengandung timbal, industri yang menggunakan timbal sebagai bahan dasar seperti industri cat, udara pada kawasan lalu lintas, pabrik pembuatan tembikar, industri baterai dan $\mathrm{aki}^{2}$

Menurut studi yang dilakukan oleh Fibrianti dan Azizah (2015) pada pekerja home industry aki bekas di Desa Talun Lamongan menunjukkan bahwa semua responden memiliki kadar timbal yang tinggi di dalam darahnya, yang mana $30 \%$ responden memiliki kadar timbal darah besar sama dari $10 \mu \mathrm{g} / \mathrm{dl} .^{3}$ Dibuktikan juga pada sebuah studi oleh Noviyanti (2012) mengenai kadar timbal dalam urin pegawai SPBU di Kota Makasar didapatkan bahwa total dari 25 responden memiliki kadar timbal urin yang tinggi. ${ }^{4}$ Manusia dapat terpapar timbal dari udara, bisa dengan menghirup udara atau menelan debu yang mengandung timbal, selain itu juga bisa melalui makanan atau meminum air yang tercemar timbal. ${ }^{5}$ Berdasarkan penelitian yang dilakukan oleh Putri (2017) di Desa Sijantang Kecamatan Talawi Kota Sawahlunto tentang konsentrasi timbal dalam air PDAM rumah penduduk, dari total 50 sampel didapatkan 31 rumah atau 62\% sampel air PDAM mengandung timbal, melebihi Nilai Ambang Batas (NAB) $0.05 \mathrm{mg} / \mathrm{L} .{ }^{6}$

Anak-anak dan balita sangat berisiko terhadap pencemaran bahan toksik seperti timbal. Timbal yang masuk kedalam tubuh anak bisa terserap hingga $50 \%$, sedangkan pada dewasa hanya berkisar 10-15\%.7 Sebuah studi yang dilakukan oleh Wagiu (2006) pada pasar di Kota Manado menunjukkan adanya hubungan antara kadar hemoglobin dengan kadar timbal darah anak, didapatkan bahwa pada anak dengan kadar timbal darah 14,2 $\mu \mathrm{g} / \mathrm{dl}$ mengalami anemia dengan kadar $\mathrm{Hb}$ 9,6 g/dl. ${ }^{8}$ Timbal yang sudah masuk kedalam tubuh akan melewati aliran darah menuju ke jaringan lunak dan akan terakumulasi ke organ-organ seperti hati, ginjal, paru-paru, otak, limpa, otot, dan jantung. Ginjal merupakan target organ yang sensitif terhadap efek toksik timbal. ${ }^{9}$ Timbal yang telah terdistribusi oleh darah akan terbawa menuju ginjal dan diekskresikan sebanyak $75-80 \%$ sebagai urin. ${ }^{10}$

Timbal dalam tingkat selular berperan sebagai radikal bebas dengan cara memicu terbentuknnya Reactive Oxygen Spesies (ROS), semakin banyak ROS maka semakin berkurang antioksidan dalam tubuh. ${ }^{11}$ Selanjutnya protein sel akan mengalami kerusakan, hal tersebut berdampak buruk terhadap kerja enzim, reseptor, transpor membran, dan DNA sebagai target utama oksidatif sehingga akan berujung pada kematian sel. ${ }^{12}$

Daun duwet (Syzigium cumini) mengandung senyawa yang beraktivitas sebagai antioksidan. Myricetin memiliki aktivitas sebagai pencegah kerusakan DNA dan quercetin berperan sebagai free radical scavenger yaitu sebagai pencegah terjadinya kerusakan komponen sel yang diakibatkan oleh radikal bebas. Myrtenol, quercetin merupakan senyawa yang termasuk kedalam golongan flavonoid dan akan berperan sebagai antioksidan tambahan dari luar tubuh. ${ }^{13}$ Menurut hasil penelitian pengaruh ekstrak daun duwet terhadap tikus yang dilakukan oleh Ningrum (2017) menunjukkan bahwa ekstrak daun duwet dengan dosis $150 \mathrm{mg} / \mathrm{kgBB}$ memiliki peran sebagai senyawa yang melindungi sel hepar dari kerusakan radikal bebas. ${ }^{14}$ Berdasarkan penelitian efek antioksidan daun duwet yang dilakukan oleh Marliani et al (2014) hasil pengujian menunjukkan aktivitas antioksidan ekstrak daun duwet cukup tinggi yaitu (IC50 12,84 ppm) dan lebih aktif dari buah duwet $(319,89 \mathrm{ppm}) .^{15}$

Berdasarkan uraian di atas, perlu dilakukan penelitian tentang pengaruh pemberian ekstrak daun duwet terhadap gambaran mikroskopis ginjal tikus yang diintoksikasi dengan timbal. 


\section{METODE}

Jenis penelitian ini adalah true experimental research dengan menggunakan pendekatan randomized post test only control group design. Objek penelitian yang digunakan yaitu hewan coba berupa tikus (Rattus norvegicus) sebanyak 15 ekor. Populasi dari sampel penelitian adalah tikus jantan berumur 2-3 bulan dengan berat badan 150-300 gram, tidak cacat anatomi dan dalam keadaan sehat yang ditandai dengan bergerak aktif.

Sampel dibagi menjadi 3 kelompok dan tiap kelompok terdiri dari 5 ekor tikus. Kelompok kontrol negatif (K-) hanya diberikan pakan standar, kelompok kontrol positif $(\mathrm{K}+)$ diberikan timbal asetat dosis 40 $\mathrm{mg} / \mathrm{kgBB} /$ hari secara oral, kelompok perlakuan (P1) diberikan timbal asetat $40 \mathrm{mg} / \mathrm{kgBB} / \mathrm{hari}$ dan diberi ekstrak daun duwet dosis $150 \mathrm{mg} / \mathrm{kgBB} / \mathrm{hari}$ secara oral. Tikus diberi perlakuan selama 28 hari dan pada hari ke-29 tikus akan dibedah dan diambil organ ginjalnya dan dibuat menjadi preparat untuk pembacaan secara mikroskopis.

Pembacaan histologi sel dilakukan dengan pembesaran 400 kali dalam lima lapangan pandang berbeda dan dibaca menggunakan skor Barthel Manja. Data hasil penelitian diolah secara statistik melalui uj parametrik One Way Annova dan dilanjutkan dengan uji Post-Hoc.

\section{HASIL}
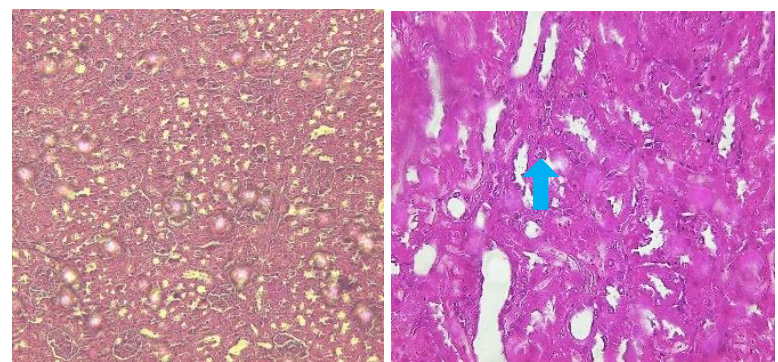

Gambar 1. Gambaran histologi ginjal tikus (kiri) kelompok kontrol negatif (K-), (kanan) kelompok kontrol positif $(\mathrm{K}+)$ terlihat gambaran karyomegali (panah biru)

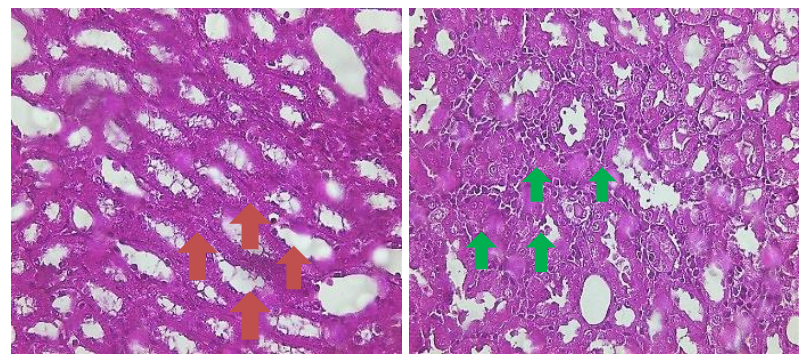

Gambar 2. Gambaran histologi ginjal tikus kelompok kontrol positif $(\mathrm{K}+)$, (kiri) terlihat gambaran sel debris (panah orange), (kanan) benda inklusi (panah hijau)

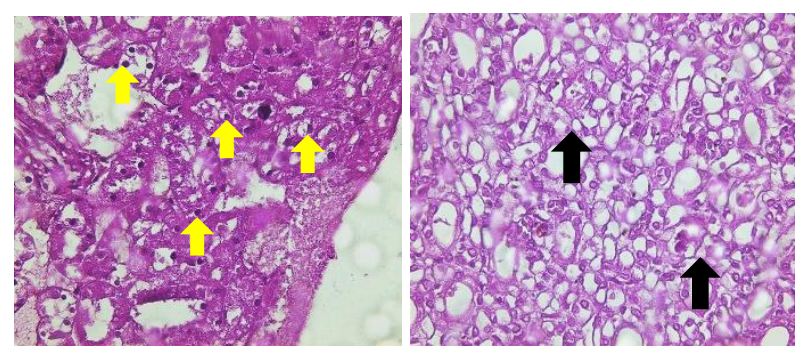

Gambar 3. Gambaran histologi ginjal tikus (kiri) kelompok kontrol positif $(\mathrm{K}+)$ terlihat gambaran degenerasi sel (panah kuning), (kanan) kelompok perlakuan (P1) terlihat gambaran vakuolisasi (panah hitam)

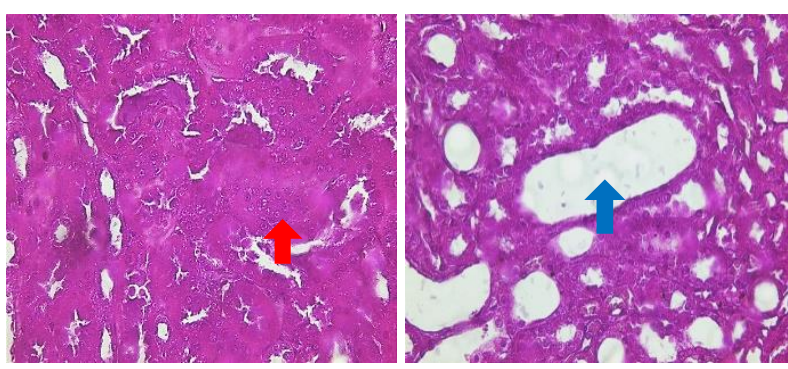

Gambar 4. Gambaran histologi ginjal tikus (kiri) kelompok kontrol positif $(\mathrm{K}+)$ terlihat gambaran hiperplasia sel (panah merah), (kanan) kelompok perlakuan $(\mathrm{P} 1)$ terlihat gambaran perlebaran lumen (panah biru) 


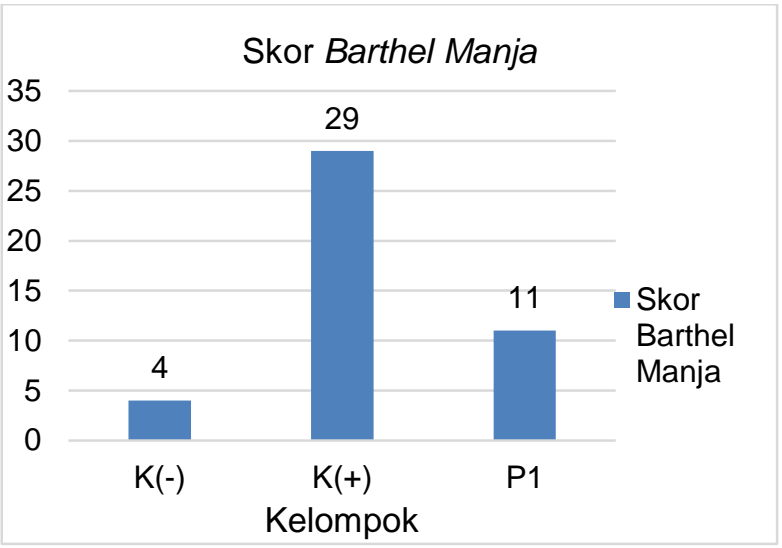

Gambar 5. Grafik total skor Barthel Manja

Grafik di atas menunjukkan bahwa terjadinya peningkatan total skor Barthel Manja pada kelompok tikus $(\mathrm{K}+)$ dan terjadi penurunan pada kelompok tikus (P1), sedangkan untuk (K-) merupakan kelompok tikus dengan skor terendah.

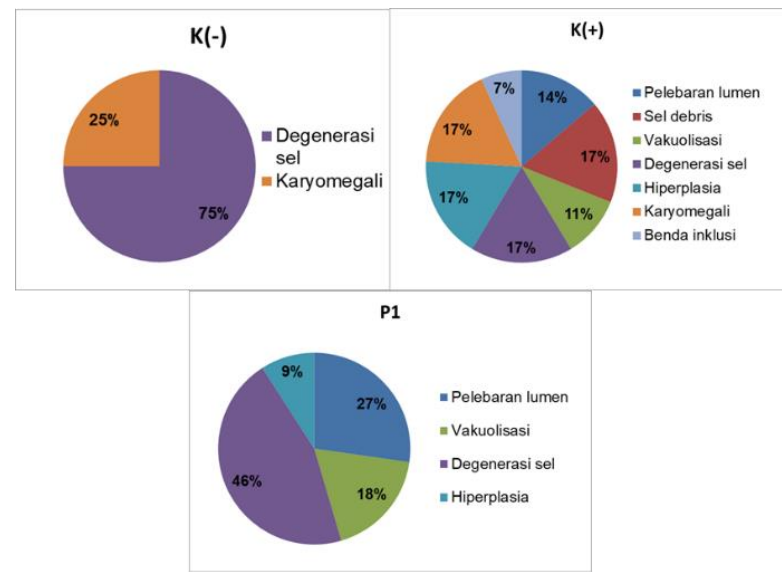

Gambar 6. Grafik skor pada kelompok (kiri) kontrol negatif, (kanan) kelompok kontrol positif, (bawah) kelompok perlakuan

Berdasarkan grafik di atas dapat dilihat bahwa pada tikus kelompok (K-) hanya ditemukan 2 jenis kerusakan dan degenerasi sel merupakan jenis kerusakan yang mendominasi yaitu sebesar $75 \%$, sedangkan pada tikus kelompok $(\mathrm{K}+)$ hampir semua jenis kerusakan ditemukan dan sel debris, degenerasi sel, hiperplasia, serta karyomegali merupakan 4 jenis yang paling dominan yaitu sebesar $17 \%$.

Grafik skor kelompok tikus (P1) didapatkan bahwa degenerasi sel merupakan jenis kerusakan yang paling dominan yaitu sebesar $46 \%$ dibandingkan 3 jenis kerusakan lainnya. Secara keseluruhan dari grafik di atas dapat diketahui bahwa degenerasi sel adalah jenis kerusakan yang paling banyak ditemukan dibandingkan jenis kerusakan lain, sedangkan untuk sel debris dan benda inklusi merupakan jenis kerusakan yang hanya dijumpai pada tikus kelompok $(\mathrm{K}+)$.

\section{Analisis Data}

Uji normalitas yang digunakan pada data penelitian ini yaitu uji Saphiro-Wilk. Uji normalitas pada data skor Barthel Manja didapatkan nilai $p>0.05$ untuk setiap kelompok oleh karena itu data tersebut terdistribusi normal. Uji One Way Anova yang dilakukan pada data skor Barthel Manja tiap kelompok menunjukkan hasil perbedaan yang bermakna dengan nilai $p=0,000(p<0,05)$.

Tabel 1. Uji post-hoc terhadap skor Barthel Manja kelompok perlakuan

\begin{tabular}{lc}
\hline \multicolumn{1}{c}{ Kelompok } & $\mathrm{p}$ \\
\hline Kontrol negatif (K-) vs kontrol positif $(\mathrm{K}+)$ & 0,000 \\
Kontrol negatif (K-) vs perlakuan (P1) & 0,029 \\
Kontrol positif (K+) vs perlakuan (P1) & 0,000 \\
\hline
\end{tabular}

Berdasarkan tabel diatas dapat dilihat bahwa uji Post-Hoc yang dilakukan pada data menunjukkan hubungan yang signifikan antara kelompok $\left(\mathrm{K}_{+}\right)$ dengan kelompok $(P 1)$ yaitu dengan nilai $p=0,000$.

\section{PEMBAHASAN}

Hasil penelitian menunjukkan peningkatan skor Barthel Manja pada gambaran histologi kelompok tikus yang diberi paparan timbal asetat $40 \mathrm{mg} / \mathrm{kgBB}$ tanpa pemberian ekstrak daun duwet, hal ini sesuai dengan penelitian yang dilakukan oleh Abshar et al (2016) bahwa terjadinya peningkatan rata-rata skor Barthel Manja pada kelompok kontrol positif $(\mathrm{K}+)$ yang menandakan semakin tingginya kerusakan struktur mikroskopis ginjal. ${ }^{16}$ Penelitian yang dilakukan oleh Hariono (2005) juga menunjukkan kesamaan yaitu terdapatnya dampak dari timbal terhadap histologi ginjal tikus, namun perbedaannya adalah terdapat pada dosis timbal $(1,5 \mathrm{mg} / \mathrm{kgBB})$ dan lama pemaparan yaitu selama 10 minggu. ${ }^{17}$

Gambaran histologi kelompok (K-) juga menunjukkan adanya kerusakan histologi berupa degenerasi sel dan karyomegali yang dapat dilihat 
pada Gambar 6, namun kerusakan tersebut masih tergolong ringan, hal ini diduga karena tikus yang digunakan bukan merupakan tikus dari kelompok SPF (Specific Pathogen Free). ${ }^{18,19}$

Timbal akan menjadi radikal bebas dengan mengganggu ikatan disulfida dan menghambat kerja beberapa enzim seperti enzim glutathione reductase, glutathione peroxidase (GPx), catalase (CAT) dan superoxide dismutase (SOD). Glutathione reductase merupakan enzim yang nantinya mengubah GSSG (Glutathione disulfide) menjadi GSH. ${ }^{20}$

Pada proses metabolisme sel, maka oksigen akan mengalami proses reduksi dan mendapatkan tambahan empat elektron sehingga menjadi air, pada saat ini kemungkinan timbal juga menjadi salah satu logam yang menerima elektron dari oksigen sehingga akan terbentuk hidrogen peroksida $\left(\mathrm{H}_{2} \mathrm{O}_{2}\right)$ dan radikal hidroksil $\left(\mathrm{OH}^{-}\right)$yang merupakan radikal bebas dalam sel. ${ }^{21}$

Timbal merusak sel dengan meningkatkan jumlah ikatan rangkap asam lemak membran sel, hal tersebut ikut menaikkan konsentrasi malondialdehid (MDA) yang merupakan penanda dari terjadinya stres oksidatif dan membuat membran sel rentan terhadap peroksidasi lipid. Membran sel yang rusak akibat peroksidasi lipid akan menghambat kerja pompa ion natrium-kalium sehingga keseimbangan osmotik lingkungan sel terganggu. Mitokondria sebagai organel penghasil energi sel (ATP) juga akan ikut terganggu. Gangguan pada membran dan mitokondria akan menyebabkan masuknya air ke intra seluler yang kemudian membentuk vakuola-vakuola yang berwarna jenih dan banyak, proses ini akan tetap berlanjut selama paparan radikal bebas masih ada. Degenerasi sel dapat terjadi jika sel tersebut tidak dapat lagi beradaptasi dan mempertahankan keutuhannya, degenerasi yang terjadi berupa degenerasi parenkimatosa dan degenerasi hidropik. ${ }^{20,21}$

Timbal juga merupakan suatu zat xenobiotik yang berefek toksik bagi sel. Zat xenobiotik dapat menimbulkan jejas sel karena berikatan secara kovalen pada bagian makromolekul sel (DNA, RNA dan protein sel). Selain itu, spesies reaktif xenobiotik yang berikatan dengan protein sel akan mengubah antigenitas sel dan menjadi hapten. Hapten tersebut akan memicu terbentuknya antibodi yang kemudian merusak sel melalui mekanisme imunologis. Reaktif spesies xenobiotik dapat bereaksi dengan enzim tubuh yang membuatnya menjadi zat karsinogenik dan menimbulkan mutasi bagi DNA. ${ }^{22}$

Beberapa kriteria yang masih ditemukan pada kelompok (P1) ada empat jenis kerusakan yaitu degenerasi sel, pelebaran lumen, vakuolisasi, dan hiperplasia. Degenerasi sel merupakan tahapan awal dari proses kematian sel. ${ }^{21}$ Ginjal sebagai organ yang adaptif akan melakukan restorasi struktur sel dan fungsinya secara sempurna serta menghentikan keadaan nefrotoksik pada keadaan toksisitas yang tidak lama atau pada kerusakan fase awal. Proses perbaikan struktur dan fungsi ginjal terjadi pada minggu pertama hingga minggu kedua fase penyembuhan dan berlangsung terus-menerus selama satu tahun sampai fungsi ginjal normal sepenuhnya. Zat-zat yang bersifat toksik dan masih menempel pada brush border tubulus proksimal serta berada pada lingkungan sel masih dapat menyebabkan kerusakan sel sampai zat-zat tersebut benar-benar habis dan dikeluarkan dari ginjal. ${ }^{18}$

Pemberian daun duwet pada sampel menunjukkan gambaran kerusakan sel yang lebih ringan dibandingkan dengan sampel yang hanya diberi timbal asetat saja. Hal tersebut dapat dilihat pada gambar 6, bahwa jenis kerusakan berupa benda inklusi, sel debris dan karyomegali tidak ditemukan pada tikus kelompok (P1). Kemungkinan kandungan zat antioksidan di dalam daun duwet dapat memengaruhi daya tahan sel ataupun dapat membantu perbaikan struktur sel ginjal. Namun perbaikan sel yang tidak sempurna atau tidak turunnya skor Barthel Manja hingga nol kemungkinan karena dosis dari ekstrak daun duwet yang diberikan belum optimal.

Senyawa flavonoid yang terkandung dalam ekstrak daun duwet memiliki beberapa mekanisme dalam fungsinya sebagai antioksidan. Pertama, senyawa flavonoid mampu menekan jumlah radikal bebas dengan cara mendonorkan atom hidrogen atau mentransfer satu elektronnya kepada radikal bebas. Kedua, flavonoid berfungsi sebagai chelating agent yang memungkinkan senyawa tersebut berikatan 
dengan ion logam. Ketiga, produksi enzim-enzim pembentuk radikal bebas seperti xanthine oxidase, protein kinase $C$, cyclooxygenase, NADPH oxidase akan ditekan. Keempat, menginduksi pembentukan enzim antioksidan alami tubuh seperti enzim superoksida dismutase (SOD), catalase dan glutation reductase. ${ }^{23}$

Senyawa quarcetin secara bioaktivitas berperan langsung dalam menstabilkan membran sel yaitu dengan cara mengurangi reaksi peroksida lipid sehingga sel lebih tahan terhadap dampak buruk dari radikal bebas. ${ }^{24}$ Myricetin berperan dalam memulihkan ekspresi protein enzim antioksidan serta mengurangi kadar $\mathrm{H}_{2} \mathrm{O}_{2}$ dalam sel. ${ }^{25}$

\section{SIMPULAN}

Terdapat perbedaan bermakna antara tikus yang hanya diberikan timbal asetat $40 \mathrm{mg} / \mathrm{kgBB}$ dengan tikus yang diberikan timbal asetat $40 \mathrm{mg} / \mathrm{kgBB}$ dan ekstrak daun duwet dosis $150 \mathrm{mg} / \mathrm{kgBB}$.

\section{UCAPAN TERIMAKASIH}

Terima kasih kepada seluruh pihak yang turut membantu dalam menyelesaikan penelitian yang berlokasi di Laboratorium Imunologi Fakultas Farmasi, Laboratorium Patologi Anatomi Fakultas Kedokteran, dan Laboratorium Histologi Fakultas Kedokteran yang berada dalam Universitas Andalas.

\section{DAFTAR PUSTAKA}

1. Iyin I, Berg T, Dutchak S, Pacyna J. Heavy metals. European Monitoring and Evaluation Programme. 2002;108-27.

2. Wani AL, Ara A, Usmani JA. Lead toxicity: a review. Interdisciplinary Toxicology. 2015;8(2):5564.

3. Fibrianti LD, Azizah R. Karakteristik, kadar timbal (Pb) dalam darah, dan hipertensi pekerja home industry aki bekas di desa Talun Kecamatan Sukodadi Kabupaten Lamongan. Jurnal Kesehatan Lingkungan. 2015;8(1):92-102.

4. Noviyanti F. Gambaran kadar timbal dalam urin pada pegawai stasiun pengisian bahan bakar umum (SPBU) di Kota Makassar [skripsi]. Makssar:
Fakultas IImu Kesehatan, Universitas Negeri Alauddin; 2012.

5. Ross GL, Ponirovskaya Y. Lead and human health. American Council on Science and Health. 2000;2:1-62.

6. Putri R. Hubungan konsentrasi timbal dalam air Perusahaan Daerah Air Minum (PDAM) dengan kejadian hipertensi di Desa Sijantang Koto Kecamatan Talawi Kota Sawahlunto [skripsi]. Padang: Fakultas Kedokteran, Universitas Andalas; 2017.

7. Albalak R, Noonan G, Buchanan S, Flanders WD, Gotway-Crawford C, Kim D, et al. Blood lead levels and risk factors for lead poisoning among children in Jakarta, Indonesia. Science of the Total Environment. 2003;301(1-3):75-85.

8. Wagiu FA, Wulur FH. Hubungan antara kadar timbal udara dengan kadar timbal darah serta dampaknya pada anak. Sari Pediatri. 2006;8:23843.

9. Abadin H, Ashizawa A, Stevens YW, Llados F, Diamond G, Sage G, et al. Toxicological profile for lead. US Department of Health and Human Services. 2007:156-75.

10. Farhan Z, Budi MS, Elmatris. Artikel penelitian efek pemberian vitamin $c$ terhadap mikroskopis ginjal tikus wistar yang terpapar plumbum asetat. Jurnal Kesehatan Andalas. 2017;6(2):417-22.

11. Jan AT, Azam M, Siddiqui K, Ali A, Choi I, Haq QMR. Heavy metals and human health: mechanistic insight into toxicity and counter defense system of antioxidants. International Journal of Molecular Sciences. 2015; 16 (12): 29592-630.

12. Lobo V, Patil A, Phatak A, Chandra N. Free radicals, antioxidants and functional foods: impact on human health. Pharmacognosy Reviews. 2010; 4(8):118-26.

13. Ramya S, Neethirajan K, Jayakumararaj R. Profile of bioactive compounds in Syzygium cumini. Journal of Pharmacy Research. 2012;5(8):454853.

14. Ningrum LP, Salim N, Balqis U. Pengaruh ekstrak daun jamblang (Syzygium Cumini L) terhadap 
histopatologi hepar tikus putih (Rattus norvegicus)

diabetes melitus. Jurnal IImiah Mahasiswa Veteriner. 2017;01(4):695-701.

15. Marliani L, Kusriani H, Sari I. Aktivitas antioksidan daun dan buah jamblang (Syzigium cumini I.). Prosiding Seminar Nasional Penelitian dan PKM. 2014;4(1):201-6.

16. Abshar I, Asri A, Elmatris. Efek pemberian vitamin e terhadap gambaran mikroskopis ginjal mencit (Mus musculus) yang terpapar ion pb asetat [skripsi]. Padang: Fakultas Kedokteran, Universitas Andalas; 2016.

17. Hariono B. Efek pemberian plumbum (timah hitam) anorgani pada tikus putih (Rattus novergicus). Jurnal Sain Veteriner. 2005;23:124-34.

18. Yulinta NMR, Gelgel KTP, Kardena IM. Efek toksisitas ekstrak daun sirih merah terhadap gambaran mikroskopis ginjal tikus putih diabetik yang diinduksi aloksan. Buletin Veteriner Udayana. 2013;5(2):114-21.

19. Suyanti L. Gambaran histopatologi hati dan ginjal tikus pada pemberian fraksi asam amino nonprotein pada uji toksisitas akut [skripsi]. Bogor: Fakultas Kedokteran Hewan, Institut Pertanian Bogor; 2008.
20. Ercal N, Gurer H, Aykin N. Toxic metals and oxidative stress part I: mechanisms involved in metal induced oxidative damage. Current Topics in Medicinal Chemistry. 2001;1(6):529-39.

21. Kumar V, Cotran RS, Robbins SL. Buku Ajar Patologi. Edisi ke-7. Penerjemah; Prasetyo A, Pendit BU, Priliono T. Jakarta: EGC;2007.hlm.3-32.

22. Murray RK, Granner DK. Metabolisme xenobiotik. Dalam: Murray RK, Granner DK, Rodwell VW, editors. Penerjemah; Brahm U.P. Biokimia Harper. Edisi ke-27. Jakarta: EGC; 2009.hlm. 653-9.

23. Banjarnahor SDS, Artanti N. Antioxidant properties of flavonoids. Medical Journal of Indonesia. 2015; 23(4):239-44.

24. Margina D, Ilie M, Manda G, Neagoe I, Mocanu M, Ionescu D, et al. Quercetin and epigallocatechin gallate effects on the cell membranes biophysical properties correlate with their antioxidant potential. General Physiology and Biophysics. 2012;31:4755.

25. Chae SC, Lee JH, Park SU. Recent studies on flavonoids and their antioxidant activities. Experimental and Clinical Sciences Journal. 2013;12:226-30. 